\title{
Enteromorpha intestinalis Derived Seaweed Liquid Fertilizers as Prospective Biostimulant for Glycine max
}

\author{
Chetna Mathur ${ }^{1}$, Saumya Rai $^{2}$, Nikhil Sase ${ }^{3}$, Suthindhiran Krish ${ }^{2}$ and Mangalam \\ Achuthanandam Jayasri ${ }^{2}$ \\ ${ }^{I}$ Marine Biotechnology ${ }^{2}$ Bio products Lab, School of Biosciences and Technology; Vellore Institute of Technology; \\ Tamilnadu - India
}

\begin{abstract}
In the present study, the potential of seaweed liquid fertilizer (SLF) of marine algae Enteromorpha intestinalis was evaluated for its effect on seed germination, yield, biochemical parameters and pigment characteristics of Glycine max. E. intestinalis was collected form Mandapam coast of Gulf of Mannar, Tamil Nadu, and the dried seaweeds were used for the preparation of SLF. G. max seeds were germinated with four different concentrations (20, 40, 60, and $100 \%$ ) of SLF; its growth and yield parameters were evaluated and compared with chemical fertilizer and control. The morphological and bio-chemical parameters such as seed germination (100\%), root (6.6cm) and shoot length $(5.4 \mathrm{~cm})$, carbohydrates $(0.098 \mathrm{mg} / \mathrm{g})$, protein $(0.56 \mathrm{mg} / \mathrm{g})$, pigment $(0.444 \mathrm{mg} / \mathrm{g} \mathrm{chl} \mathrm{a} ; 1.073 \mathrm{mg} / \mathrm{g} \mathrm{chl} \mathrm{b;} 3.70$ $\mathrm{mg} / \mathrm{g}$ carotenoids) of the plant was found maximum at a concentration of $60 \% \mathrm{SLF}$. The phenol content $(3.25 \mathrm{mg} / \mathrm{g})$ was maximum in 40\% SLF. The GC-MS analysis of SLF revealed the presence of notable benzoic compounds involved in plant growth promotion. Results showed that $\mathrm{E}$. intestinalis derived SLF was potential biostimulant for G. max. Thus, marine algae based fertilizer could be an effective and alternate to the chemical fertilizers emphasizing the need for systematic evaluation programme for SLF on various crops.
\end{abstract}

Key words: Marine algae; Enteromorpha intestinalis, Glycine max (L.) Merr, Seaweed liquid fertilizer, plant growth

\section{INTRODUCTION}

Excess uses of chemical fertilizers have been a great concern because of their adverse effects on the crops and in the soil fertility. Organic fertilizers from plant and animal matter are one of the main source of plant growth promoting hormones, antibiotics, vitamins, amino acids, micronutrients which stimulates plant growth and protect against the diseases. Seaweed liquid fertilizers (SLF) are considered to be better and effective than chemical fertilizer. Seaweeds are rich sources of macro nutrients, and trace elements necessary for the growth and enhancement of the plants; and bio-farming using seaweeds has been practiced from ancient time. Seaweeds have been exploited their ability to enhance seed germination; they impart resistance to frost, fungal and insect attack and increase nutrient uptake from soil (Venkataraman 1993; Mohan 1994). Bioassays to evaluate the growth promoting effect of seaweed extracts have shown that the beneficial effect of these extracts are due to synergetic effect of plant growth-promoting substances or hormones present in seaweeds (Williams et al. 1981; Tay et al. 1985; Mooney and van Staden 1986; Rayorath et al. 2008; Khan et al. 2009; Wally et al. 2013; Jannin et al. 2013). Marine seaweeds are rich in potassium and contain many growth promoters such as auxins, gibberellins, cytokinins and are

*Author for correspondence: jayasri.ma@vit.ac.in 
also used as good soil conditioners. Hence, the present study investigated the potential of marine algae Enteromorpha intestinalis on the growth and productivity of Glycine max.

\section{MATERIAL AND METHODS}

\section{Collection and Identification of Seaweeds}

Seaweeds were collected from Mandapam coast, Gulf of Mannar, Tamilnadu, India. It was washed with sea water to remove the unwanted weeds, sand, and epiphytes. Seaweeds were again washed thoroughly with tap water for 3-4 times to remove the salts and were spread on blotting paper to remove the excess water. These seaweeds were cleaned, and holdfasts were removed and stored at $-20^{\circ} \mathrm{C}$ immediately. The morphology of the algal sample was studied by phase contrast microscopy (Labomed, India) connected with the microscopic camera. The voucher specimen was deposited in the Marine Biotechnology and Biomedicine Laboratory, VIT University.

\section{Preparation of Seaweed Liquid Fertilizer (SLF)} The seaweed liquid fertilizer was prepared as described earlier (Bhosle et al. 1975). Briefly, the dried seaweeds were autoclaved for one hour. The extract was filtered through a cheese cloth and allowed to cool. The filtrate was collected and centrifuged at $10,000 \mathrm{~g}$ at $4^{\circ} \mathrm{C}$ for $30 \mathrm{~min}$. Then the supernatant was collected and taken as $100 \%$ seaweed extract. The SLF was then diluted with distilled water to make various concentrations such as 60,40 , and $20 \%$.

\section{Seed Preparation}

Seeds of Glycine $\max$ (L.) Merr were bought from the local market in Vellore. The seeds were soaked in the different concentration of SLFs for $12 \mathrm{~h}$. Ten seeds with each concentration of SLF were sowed in different pots.

\section{Maintenance of Seeds}

Seeds were maintained in three different treatments

Control seeds - Ten seeds were directly sown in a pot without any supplement.

Seeds with Chemical fertilizer- Ten seeds were directly sown in a pot along with $5.0 \mathrm{~g}$ of urea (Tata Chemical Ltd, India).

Seeds with SLF: Ten seeds were maintained with different concentrations of SLF (20, 40, 60 and $100 \%$ ) Seeds in all the six pots (control, chemical fertilizer, SLF) were allowed to grow for 60 days, with proper watering and with essential amount of sunlight. The pots were kept in the shade to prevent them from rain water. After attaining proper growth after 60 days, the plants were uprooted and subjected to various bioassays.

\section{Biostimulant Assays Seed Germination}

Ten seeds of $G . \max$ (L.) Merr were sowed in each pot. The number of seeds germinated was recorded on the $15^{\text {th }}$ day after the sowing.

\section{Root and Shoot length}

After 60 days of growth, one plant from each pot was uprooted carefully, and the root length and shoot length were measured.

\section{Biochemical Assays}

The biochemical estimations and pigments such as chlorophylls and carotenoids were measured in control and treated plants using standard protocols. Estimation of Carbohydrates was done by phenolsulphuric acid assay (Hodge et al. 1962). Briefly, $20 \mathrm{mg}$ of plant leaf sample were washed with distilled water and air dried. Leaves with $1.0 \mathrm{~mL}$ of distilled water were crushed in mortal-pestle. Sample mixture was then heated in water bath at $70^{\circ} \mathrm{C}$ for $20 \mathrm{~min}$ and subsequently centrifuged at $3577 \mathrm{xg}$ at $4^{0} \mathrm{C}$ for $15 \mathrm{~min}$. After centrifugation, supernatant was collected from the sample mixture and used as extract for the estimation. Protein content was estimated taking BSA as a standard (Bradford 1976). For this, $20 \mathrm{mg}$ of leaf sample from each pot was crushed in mortal-pestle with $1.5 \mathrm{~mL}$ of distilled water. The homogenate was centrifuged at $14000 \mathrm{xg}$ at $4^{\circ} \mathrm{C}$ for $10 \mathrm{~min}$. The supernatant was collected and used as leaf extract for the estimation of protein. The amount of protein content was calculated by plotting a standard curve. The amino acid content of control and test samples of G. $\max$ (L.) Merr was separated by paper chromatography technique. For this, $50 \mathrm{mg}$ of weighted leaf samples were crushed in mortal-pestle with $1-2 \mathrm{~mL}$ of $80 \%$ ethanol. The homogenate was centrifuged at 5000 $\mathrm{g}$ at $4^{0} \mathrm{C}$ for $10 \mathrm{~min}$. The supernatant was used for amino acid separation and estimation using Whatman No.1 filter paper. The Rf values of the samples were calculated as described earlier (Block et al. 1955). Phenol content was measured using Folin-ciocalteu reagent as described earlier (Shozeb Javed and Aruna Panwar 2013). Briefly, 
$20 \mathrm{mg}$ of plant leaf samples were crushed with 1.0 $\mathrm{mL}$ of $80 \%$ ethanol in mortar-pestle. The crushed mixture of leaf samples were centrifuged at 14000 $\mathrm{xg}$ at $4^{\circ} \mathrm{C}$ for $20 \mathrm{~min}$. Supernatant was collected from the sample mixture and used for the estimation. Standard graph of phenol was plotted, and concentrations of phenol in the test samples were estimated. For the estimation of total phenol content, gallic acid was used as standard solution (25 $\mathrm{mg} / 20 \mathrm{~mL}$ ). Total phenol content was expressed in terms of gallic acid $(\mathrm{mg} / \mathrm{g})$.

For pigment estimation, $20 \mathrm{mg}$ of leaf samples were ground with $2.0 \mathrm{~mL}$ of $80 \%$ acetone. The homogenate was centrifuged at $14000 \mathrm{xg}$ at $4^{\circ} \mathrm{C}$ for $10 \mathrm{~min}$. The supernatant was measured on colorimeter at 645,663 , and $470 \mathrm{~nm}$ to determine the presence of chlorophyll a, chlorophyll $\mathrm{b}$, and carotenoids respectively. All the experiments were carried out in triplicates and results expressed as mean \pm SEM.

\section{Gas Chromatography and Mass Spectrometry Analysis of SLF}

The GC-MS analysis was carried out using a Perkin Elmer Gas Chromatograph (Model clarus680), MS transfer line temperature of $230^{\circ} \mathrm{C}$. The oven temperature was held at $60^{\circ} \mathrm{C}$ for $6 \mathrm{~min}$ and raised to $300^{\circ} \mathrm{C}$ at a rate of $10^{\circ} \mathrm{C} / \mathrm{min}$, employing helium gas $(99.999 \%)$ as a carrier gas at a constant flow rate of $1.0 \mathrm{~mL} / \mathrm{min}$. An aliquot of $1.0 \mu \mathrm{L}$ of extract at a split ratio of $10: 1$ was injected at $250^{\circ} \mathrm{C}$. MS analysis was carried out on model clarus 600(EI) coupled to Perkin ElmerGas Chromatograph (Model clarus680) equipped with 13IS-2000 Library software database. The mass spectrum of the unknown individual compound was compared with the known compounds stored in the software database Library. The compounds were identified based on the molecular structure, molecular mass and calculated fragment ratio of resolved spectra. Spectral data were interpreted using the database of National Institute Standard and Technology (NIST).

\section{RESULTS}

\section{Collection and Identification of Samples}

The algae were associated with rocky sand shores. It had tubular thalli with the single cell layer thickness (monostromatic). The characteristic presence of rounded-rectangular cells in short longitudinal rows was observed. In its natural habitat, it existed as tufts or clusters attached to the rock surface. Based on macroscopic and microscopic observations (Figs. 1A and B), the seaweed was identified as green macro marine algae Enteromorpha intestinalis and also authenticated by Dr. P. Kaladharan Principle Scientist and Scientist in Charge, Calicut Regional Centre of Central Marine Fisheries Research Institute.

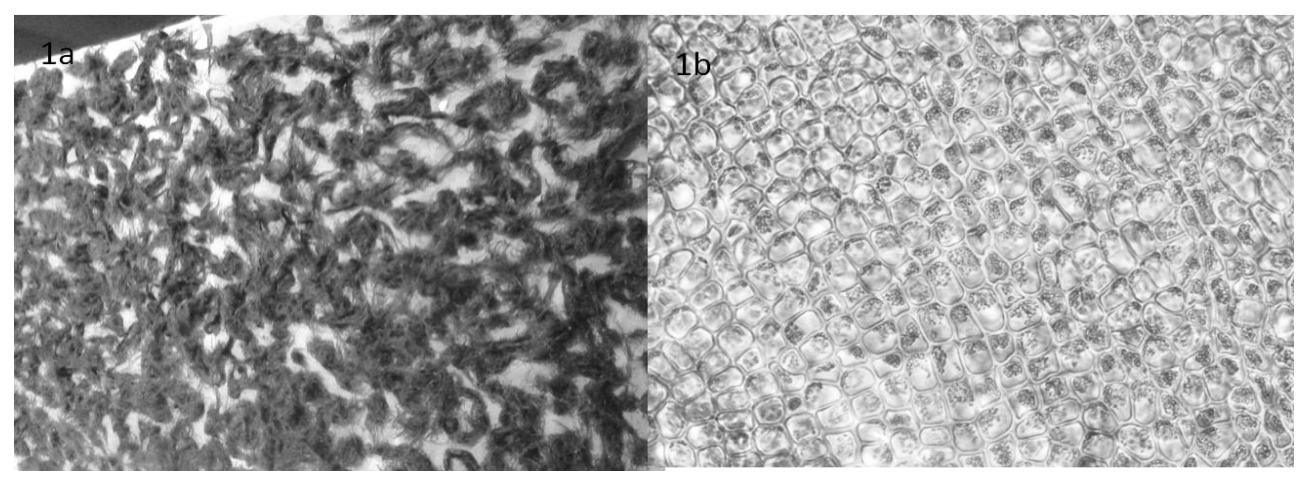

Figure 1 - Morphologial features of Enteromorpha intestinalis. (A) Macroscopic picture of $E$. intestinalis. (B) Microscopic picture of E. intestinalis. Tubular thalli with the single cell layer thickness (monostromatic) and the presence of rounded-rectangular cells in short longitudinal rows are seen.

\section{Seed Germination}

The germination percentage of control, SLF, and chemical fertilizer treated seeds are shown in (Table 1$)$. The maximum percentage $(100 \%)$ of seeds germinated was observed in $60 \%$ SLF on the $15^{\text {th }}$ day where all the ten seeds germinated. At the $100 \%$ SLF, the percentage was reduced to $40 \%$. In the control, only two out of ten seeds were 
germinated (20\%). The seed germination percentage of chemical fertilizer was $30 \%$, i.e., three out of ten seeds were germinated.

\section{Root and Shoot length}

After 60 days, the maximum root length was observed in $60 \%$ SLF that was $6.6 \mathrm{~cm}$ (Fig. 2C); the minimum root length was in control that was $3.7 \mathrm{~cm}$ whereas the root length of chemical fertilizer was $4.0 \mathrm{~cm}$. In 40 and $100 \% \mathrm{SLF}$, the root length was 5.0 and $5.2 \mathrm{~cm}$, respectively (Fig. 2B, Fig. 2D). The maximum shoot length was in $100 \%$ SLF that was $5.7 \mathrm{~cm}$ (Fig. 2d); the minimum shoot length was in control, which was $3.5 \mathrm{~cm}$. The shoot length of chemical fertilizer was found to be $3.6 \mathrm{~cm}$ after 15 days. At $60 \%$, SLF the shoot length was $5.4 \mathrm{~cm}$ that was comparable to that of $100 \%$ SLF (Table 1).

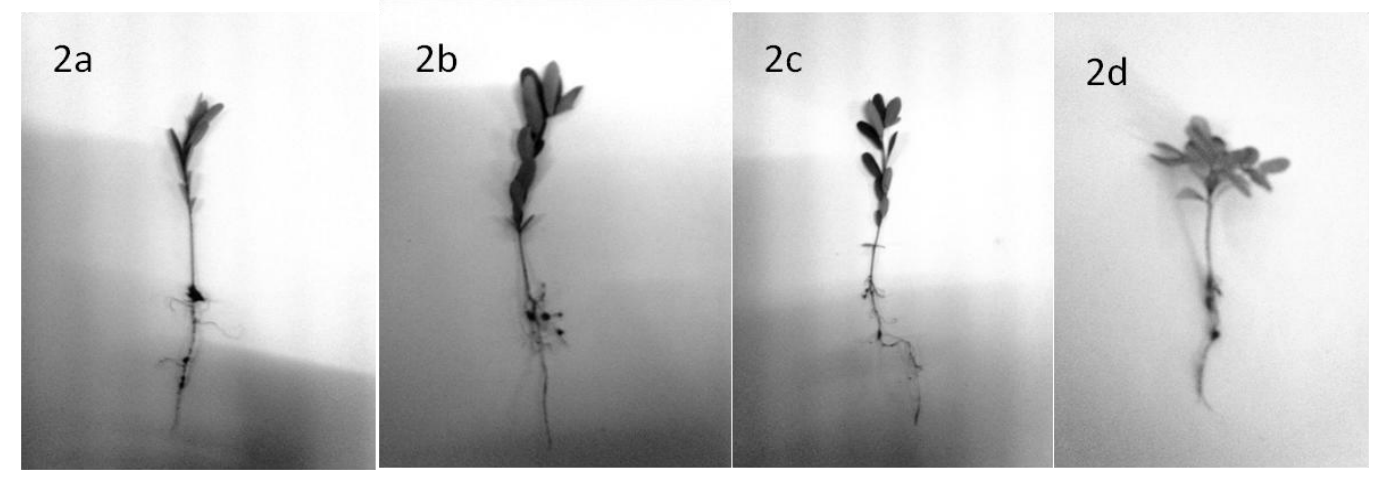

Figure 2 - Effect of various concentrations of SLF of the root and shoot length of Glycine max (A) In $20 \%$ SLF root lengths is $4.5 \mathrm{~cm}$. And shoot length is $4.1 \mathrm{~cm}$. (B) In $40 \%$ SLF the root length is $5.0 \mathrm{~cm}$. and shoot length is $4.4 \mathrm{~cm}$. (C) In $60 \%$ SLF root length is $6.6 \mathrm{~cm}$ and shoot length is 5.4 . (D) In $100 \%$ SLF root length is $5.2 \mathrm{~cm}$ shoot length is $5.7 \mathrm{~cm}$.

\section{Estimation of Carbohydrate Content in the Plants}

The carbohydrate content was maximum in $60 \%$ SLF $(0.098 \mathrm{mg} / \mathrm{g})$, minimum in $20 \%$ SLF $(0.008$ $\mathrm{mg} / \mathrm{g}$ ); in the chemical fertilizer ( $5 \mathrm{~g}$ of urea), it was $0.038 \mathrm{mg} / \mathrm{g}$. In the control, the carbohydrate content was $0.006 \mathrm{mg} / \mathrm{g}$ (Table 1).

\section{Estimation of Phenol Content in the Plants}

The total phenol content in G. $\max$ (L.) Merr was $3.50 \mathrm{mg} / \mathrm{g}$ in $40 \%$ SLF and $1.10 \mathrm{mg} / \mathrm{g}$ in control. The total phenol content in the chemical fertilizer was $1.23 \mathrm{mg} / \mathrm{g}$. At $60 \% \mathrm{SLF}$, the phenol content was 3.25 which were related to $40 \%$ SLF (Table $1)$.

\section{Estimation Protein Content in the Plants}

The total protein content was observed maximum in $60 \% \mathrm{SLF}(0.56 \mathrm{mg} / \mathrm{g})$, the minimum phenol content was in control $(0.13 \mathrm{mg} / \mathrm{g})$ whereas in chemical fertilizer it was measured as $0.19 \mathrm{mg} / \mathrm{g}$. At $100 \%$ SLF, the protein content was greatly reduced to $0.17 \mathrm{mg} / \mathrm{g}$ (Table 1 ).

Estimation of Amino Acids Content in the Plant The amino acid content of G. $\max (\mathrm{L}$.) Merr was 0.86 in $60 \%$ SLF after 15 days and 0.18 in $20 \%$
SLF. The amino acid content in the chemical fertilizer was 0.78 and in control, it was 0.69 (Table 1).

\section{Estimation of Pigments in the Plant}

The maximum amount of chlorophyll a was 0.44 $\mathrm{mg} / \mathrm{g}$ in $60 \% \mathrm{SLF}$; the minimum was $0.044 \mathrm{mg} / \mathrm{g}$ in the control and in the chemical fertilizer it was $0.076 \mathrm{mg} / \mathrm{g}$. The chlorophyll $\mathrm{b}$ content was 1.073 $\mathrm{mg} / \mathrm{g}$ in $60 \% \mathrm{SLF}, 0.39 \mathrm{mg} / \mathrm{g}$ in the chemical fertilizer and $0.02 \mathrm{mg} / \mathrm{g}$ in control. Carotenoids were $3.70 \mathrm{mg} / \mathrm{g}$ in $60 \% \mathrm{SLF}, 1.97 \mathrm{mg} / \mathrm{g}$ in the chemical fertilizer and $1.43 \mathrm{mg} / \mathrm{g}$ in the control after 15 days (Table 1 ).

\section{Gas Chromatography and Mass Spectometry Analysis}

The GC-MS analysis revealed the presence of various compounds present in the SLF sample. The gas chromatogram of the extract showed 56 peaks. However, only 12 major compounds were identified to have plant growth regulation properties (Table 2). The major compound present in the SLF extract of E. intestinalis was 1,3Dihydro-1-(2,6-dichlorophenyl)-2H-indol-2-one $\left(\mathrm{C}_{14} \mathrm{H}_{9} \mathrm{ONC}_{12}\right)$ with RT: 20.125. The molecular 
weight was 277. Other notable compounds identified in the SLF extract of E. intestinalis included benzene, 1-chloro-2-(2-phenylethenyl)-; benzene, 1,1'-(1-chloro-1,2-ethenediyl) bis- ; diclofenac, methyl ester; benzene, 1-chloro-4-(2- phenylethenyl)-;

benzene,

$1,1^{\prime}-$

(chloroethenylidene) bis- ; benzene, 1-chloro-3-(2phenylethenyl)-, (E)- ; benzene acetic acid. All these compounds were found to have one or more plant growth promoting activities (Table 2).

Table 1 - Effect of Enteromorpha intestinalis derived SLF on morphological and biochemical parameters of G. max (L.) Merr. The results were compared with the chemical fertilizer treated seeds.

\begin{tabular}{|c|c|c|c|c|c|c|c|c|c|c|c|}
\hline $\begin{array}{l}\text { S. } \\
\text { No }\end{array}$ & Treatments & $\underset{\%}{\text { Germination }}$ & $\begin{array}{c}\text { Root } \\
\text { length } \\
(\mathrm{cm})\end{array}$ & $\begin{array}{c}\text { Shoot } \\
\text { length } \\
\text { (cm) }\end{array}$ & $\begin{array}{l}\text { Carbohydrate } \\
\text { content(mg/g) }\end{array}$ & $\begin{array}{c}\text { Phenol } \\
\text { content } \\
(\mathrm{mg} / \mathrm{g})\end{array}$ & $\begin{array}{l}\text { Protein } \\
\text { content } \\
(\mathrm{mg} / \mathrm{g})\end{array}$ & $\begin{array}{c}\text { Amino } \\
\text { acid } \\
(\mathrm{mg} / \mathrm{g})\end{array}$ & $\begin{array}{l}\text { Chl. a } \\
(\mathrm{mg} / \mathrm{g})\end{array}$ & $\begin{array}{l}\text { Chl. b } \\
\text { (mg/g) }\end{array}$ & $\begin{array}{c}\text { Carotenoids } \\
(\mathrm{mg} / \mathrm{g})\end{array}$ \\
\hline 1 & $20 \%$ SLF & 40 & 4.5 & 4.1 & 0.008 & 1.25 & 0.15 & 0.18 & 0.071 & 0.25 & 2.77 \\
\hline 2 & $40 \% \mathrm{SLF}$ & 70 & 5.0 & 4.4 & 0.021 & 3.50 & 0.27 & 0.66 & 0.182 & 0.653 & 3.07 \\
\hline 3 & $60 \%$ SLF & 100 & 6.6 & 5.4 & 0.098 & 3.25 & 0.56 & 0.86 & 0.444 & 1.073 & 3.70 \\
\hline 4 & $100 \%$ SLF & 40 & 5.2 & 5.7 & 0.040 & 2.90 & 0.17 & 0.68 & 0.130 & 0.456 & 2.48 \\
\hline 5 & $\begin{array}{l}\text { Chemical } \\
\text { fertilizer }\end{array}$ & 32 & 4.0 & 3.6 & 0.038 & 1.23 & 0.19 & 0.78 & 0.076 & 0.39 & 1.97 \\
\hline 6 & Control & 20 & 3.7 & 3.5 & 0.006 & 1.10 & 0.13 & 0.16 & 0.044 & 0.02 & 1.43 \\
\hline
\end{tabular}

Table 2 - GC-MS Profile of SLF prepared from Enteromorpha intestinalis. Compounds with reported plant growth promotion activity only are shown.

\begin{tabular}{|c|c|c|c|c|c|c|c|}
\hline $\begin{array}{c}\text { S } \\
\text { No. }\end{array}$ & Compound Name & M.W. & Formula & $\begin{array}{l}\text { CAS } \\
\text { No. }\end{array}$ & R.T. & $\begin{array}{l}\text { Physico-chemical } \\
\text { properties }\end{array}$ & $\begin{array}{l}\text { Biological activity on plant } \\
\text { growth promotion }\end{array}$ \\
\hline 1. & $\begin{array}{l}\text { 1,3-Dihydro-1-(2,6- } \\
\text { dichlorophenyl)-2H-indol-2-one }\end{array}$ & 277 & $\begin{array}{l}\mathrm{C} 14 \mathrm{H} 9 \mathrm{ON} \\
\mathrm{Cl} 2\end{array}$ & $\begin{array}{l}15362- \\
40-0\end{array}$ & 20.125 & $\begin{array}{l}\text { Off white to light } \\
\text { brown solid }\end{array}$ & Potent herbicide \\
\hline 2. & $\begin{array}{l}\text { 1-chloro-4-[(2- } \\
\text { phenylethenyl)sulfanyl]benzene }\end{array}$ & 214 & $\begin{array}{l}\mathrm{C} 14 \mathrm{H} 11 \\
\mathrm{ClS}\end{array}$ & $\begin{array}{l}24942- \\
76-5\end{array}$ & 20.17 & - & Pesticide \\
\hline 3. & $\begin{array}{l}\text { Benzene, 1,1'-(1-Chloro-1,2- } \\
\text { ethenediyl)bis }\end{array}$ & 214 & $\mathrm{C} 14 \mathrm{H} 11 \mathrm{Cl}$ & $\begin{array}{l}1460- \\
06-6\end{array}$ & 20.23 & B.p. $-322^{\circ} \mathrm{C}$ & Pesticide \\
\hline 4. & Diclofenac, Methyl ester & 309 & $\begin{array}{l}\mathrm{C} 15 \mathrm{H} 13 \mathrm{O} 2 \\
\mathrm{NCl} 2\end{array}$ & $\begin{array}{l}15307- \\
78-5\end{array}$ & 20.30 & $\begin{array}{l}\text { Off white solid } \\
\text { Mp- } 96-99^{\circ} \mathrm{C} \\
\text { Soluble in } \\
\text { dichloromethane }\end{array}$ & Herbicide \\
\hline 5. & $\begin{array}{l}\text { Benzene, 1-Chloro-4-(2- } \\
\text { Phenylethenyl) }\end{array}$ & 214 & $\mathrm{C} 14 \mathrm{H} 11 \mathrm{Cl}$ & $\begin{array}{l}4714- \\
23-2\end{array}$ & 20.77 & $\begin{array}{l}\text { Mp. }-81-83^{\circ} \mathrm{C} \\
\text { Bp. }-324.8^{\circ} \mathrm{C}\end{array}$ & Pesticide \\
\hline 6. & $\begin{array}{l}\text { Benzene, 1,1'- } \\
\text { (Chloroethenylidene)bis- }\end{array}$ & 214 & $\mathrm{C} 14 \mathrm{H} 11 \mathrm{Cl}$ & $\begin{array}{l}4541- \\
89-3\end{array}$ & 21.36 & Bp. $-372.5^{\circ} \mathrm{C}$ & $\begin{array}{l}\text { Pesticide, fungicide and growth } \\
\text { regulator }\end{array}$ \\
\hline 7. & $\begin{array}{l}\text { Benzene, 1-Chloro-3-(2- } \\
\text { Phenylethenyl)-, (E) }\end{array}$ & 214 & $\mathrm{C} 14 \mathrm{H} 11 \mathrm{Cl}$ & $\begin{array}{l}14064- \\
43-8\end{array}$ & 24.80 & - & $\begin{array}{l}\text { Pesticide; for enhancement of } \\
\text { tolerance to high or low } \\
\text { temperature and drought, for } \\
\text { growth regulating activities }\end{array}$ \\
\hline 8. & $\begin{array}{l}\text { Benzene, 1-Chloro-3-(2- } \\
\text { Phenylethenyl) }\end{array}$ & 214 & $\mathrm{C} 14 \mathrm{H} 11 \mathrm{Cl}$ & $\begin{array}{l}24942- \\
77-6\end{array}$ & 25.84 & - & $\begin{array}{l}\text { Pesticide; for enhancement of } \\
\text { tolerance to high or low } \\
\text { temperature and drought, for } \\
\text { growth regulating activities }\end{array}$ \\
\hline 9. & $\begin{array}{l}\text { Benzene, 1,1'-(1-Chloro-1,2- } \\
\text { Ethenediyl)bis-, (E) }\end{array}$ & 214 & $\mathrm{C} 14 \mathrm{H} 11 \mathrm{Cl}$ & $\begin{array}{l}948- \\
98-1\end{array}$ & 26.49 & - & $\begin{array}{l}\text { Pesticide, fungicide and growth } \\
\text { regulator }\end{array}$ \\
\hline 10 & $\begin{array}{l}\text { Benzeneacetic acid, 2-[(2,6- } \\
\text { Dichlorophenyl)amino] }\end{array}$ & 295 & $\begin{array}{l}\mathrm{C} 14 \mathrm{H} 11 \mathrm{O} 2 \\
\mathrm{NCl} 2\end{array}$ & $\begin{array}{l}15307- \\
86-5\end{array}$ & 28.87 & $\begin{array}{l}\text { White solid } \\
\text { Bp. }-412^{\circ} \mathrm{C} \\
\text { Mp. }-280-283^{\circ} \mathrm{C} \\
\text { Soluble in water } \\
\text { Density- } 1.431 \mathrm{~g} / \mathrm{cm}^{3}\end{array}$ & $\begin{array}{l}\text { Plant growth regulator, algicide } \\
\text { and herbicide }\end{array}$ \\
\hline 11 & $\begin{array}{l}\text { Benzoic acid, 2-[(2,6-Dichloro- } \\
\text { 3-Methylphenyl)amino]-, Methyl } \\
\text { ester }\end{array}$ & 309 & $\begin{array}{l}\mathrm{C} 15 \mathrm{H} 13 \mathrm{O} 2 \\
\mathrm{NCl} 2\end{array}$ & $\begin{array}{l}3254- \\
79-3\end{array}$ & 29.46 & Bp. $-378.2^{\circ} \mathrm{C}$ & $\begin{array}{l}\text { Herbicide and plant growth } \\
\text { regulator }\end{array}$ \\
\hline 12 & 5-Chloro-1,10-Phenanthroline & 214 & $\begin{array}{l}\mathrm{C} 12 \mathrm{H} 7 \mathrm{~N} 2 \\
\mathrm{Cl}\end{array}$ & $\begin{array}{l}4199- \\
89-7\end{array}$ & 30.06 & $\begin{array}{l}\text { Bp. }-397.4^{\circ} \mathrm{C} \\
\text { Mp. }-123-126^{\circ} \mathrm{C} \\
\text { Soluble in methanol }\end{array}$ & Acts as ligand specific chelator \\
\hline
\end{tabular}




\section{DISCUSSION}

Seaweed based liquid fertilizer show significant effects as a source of biostimulant for agriculture crops. The present study highlights the efficiency of SLF prepared from marine algae E. intestinalis on the growth and development of G. $\max (\mathrm{L}$.) Merr. Seeds soaked in the SLF gave better results than chemical fertilizer and control. The seeds treated with $60 \%$ SLF showed $100 \%$ seed germination which was in accordance with the previous report (Pise and Sabale 2010). Enhancement of the plant growth might be due to the presence of various growths promoting factor in SLF. Similar results were observed on the SLF prepared using Chaetomorpha antennina on the seed germination, fruit settling and weight of vegetable of Abelmoschus esculenus (Thirumaran et al. 2006). Mohan et al. (1994) observed that padina induced maximum seedling growth at a lower concentration in $C$. cajan. The growth promoting factors like IAA and IBA Gibberlins $(\mathrm{A} \& \mathrm{~B})$, micronutrients, vitamins and amino acids have a marked influence on the germination rate whereas retarded growth effects at higher concentration can be attributed to excessive hormones or high concentration of minerals present (Challen and Hemingway 1965). In the present study, among the seeds treated with four different concentrations of SLF, control, and chemical fertilizer, the maximum root and shoot length were observed as $6.6 \mathrm{~cm}$ and $5.4 \mathrm{~cm}$ in $60 \%$ SLF.

The studies on the biochemical parameters of $G$. $\max (\mathrm{L}$.) Merr showed that the carbohydrate and amino acid was maximum in $60 \%$ SLF that was calculated to be $0.098 \mathrm{mg} / \mathrm{g}$ and $0.86 \mathrm{mg} / \mathrm{g}$ respectively. A similar result was obtained by in the H. musicformis with NPK application in black gram seeds that was with 50\% SLF (Tamilselvan and Kannan 1994). The highest protein content was recorded at $60 \%$ SLF $(0.56 \mathrm{mg} / \mathrm{g})$ which was similar to the results of earlier studies (Kannan 1994). The increase in the protein content of SLF treated plant could be due to absorption of most of the necessary elements by the seedlings (Tamilselvan 1994; Anantharaj and Venkatesalu 2001, 2002).

The study showed that the phenol content was high $(3.50 \mathrm{mg})$ in $40 \%$ SLF. Similarly the studies on the antibiotic properties of filamentous green algae Chaetomorpha highlighted the presence of high phenolic content and more antioxidant activity. It has been shown that the marine algae are rich in the phenolic compound and serve as effective antioxidant (Luo et al. 2010).

All the tested pigments were higher in 60\% SLF. Total chlorophyll and carotenoids content was also increased by the SLF treatment. These results were found similar to some earlier findings that observed that the application of SLF on Ascophyllum nodosum increased the chlorophyll of cucumber cotyledons and tomato plants (Whapham et al. 1993). Gracilaria edulis extract on Vigna unguiculata and Phaseolus mungo (Lingakumar et al. 2002), Caulerpa scalpelliformis, and Gracilaria corticata extract on Cyamoposis tetragonoloba also shown to have an positive impact (Thirumal et al. 2003).

The seaweed liquid fertilizer prepared from $E$. intestinalis showed good fertilizing ability. These results were, in accordance with earlier findings. Blunden et al. (1996) reported that the seaweed extract applied as foliar spray enhanced the leaf chlorophyll level in the plants. The application of SLF of Ascophyllum nodosum increased the chlorophyll of cucumber cotyledons and tomato plants (Whapham et al. 1993).

Fifty-six compounds were identified from the SLF as analyzed by GC-MS. Among these, 12 peaks corresponding to benzoic compounds have been previously reported as effective pesticides, herbicides and plant growth regulating agents (Shukla et al. 1998). 5-Chloro-1,10-Phenanthroline acts as specific ligand chelator (Yanagisawa 1995). 2H-Indol-2-One, 1-(2,6-Dichlorophenyl)1,3-Dihydro- acts as an indicator for the presence of diclofenac that is an potent herbicide. Benzeneacetic acid, 2-[(2,6-Dichlorophenyl) Amino]- acts as plant growth stimulant, algicidal and herbicidal (Shukla et al. 1998). The presence of these compounds gave an insight into the plant growth regulating properties of $E$. intestinalis derived SLF. Seaweeds prove to be a good source of organic liquid fertilizer for increasing the crop yield as well as to improve the soil fertility.

\section{CONCLUSION}

From this study, it could be concluded that $60 \%$ SLF prepared from the marine algae E. intestinalis showed significant growth and development of $G$. max (L.) Merr as compared with other concentrations of SLF, chemical fertilizer, and control. Thus, this gave an insight that the marine 
algae could be an alternate source for the plant growth promotion. The study shows that the seaweed liquid fertilizer was very useful in the agricultural sector in the large scale as well. Further research on the possible use of $E$. intestinalis based SLF on other agricultural crops and in large scale usage would unveil the potential of its commercialization.

\section{ACKNOWLEDGEMENT}

The study was supported by the institutional grant, and the authors wish to thank the management, VIT University for providing necessary facilities.

\section{REFERENCES}

Anantharaj M, Venkatesalu V. Effect of seaweed liquid fertilizer on Vigna catajung. Seaweed Res Utalin. 2001; 23: 33-39.

Anantharaj M, Venkatesalu V. Studies on the effect of seaweed extracts on DolichosbiXorus. Seaweed Res Utailn. 2002; 24: 129-137.

Bhosle NB, Untawale AG, Dhargalkar VK. Effects of seaweed extract on the growth of Phaseolus vulgaris. L. Ind J Mar Sci. 1975; 4: 208-210.

Block RJ, Durrum EL, Zweig G. A Manual of Paper Chromatography and Paper Electrophoresis. Academic Press, I.N.C Publishers New York, p, 1955, 484p.

Blunden G, Jenkins T, Liu YW. Enhanced chlorophyll levels in plants treated with seaweed extract. J Appl Phycol. 1996; 8: 535-543.

Bradford MM. Rapid and sensitive method for the quantitation of microgram quantities of protein utilizing the principle of protein-dye binding. Anal Biochem. 1976, 72: 248-254.

Challen SB, Hemingway JC (1965). Growth of higher plants in response to feeding with seaweed extracts. Proc $5^{\text {th }}$ Ind Seaweed Symposium.

Hansra BS. Transfer of agricultural technology on irrigated agriculture. Fertilizer News. 1993; 38: 3133.

Hodge JE, Hofreiter BT. In: Methods in Carbohydrate Chemistry. Eds. Whistler, R.L. and Be Miller, J.N. Academic Press New York, 1962.

Jannin L, Mustapha A, Philippe E, Philippe L, Didier G, Maria G, et al. Brassica napus Growth is Promoted by Ascophyllum nodosum(L.) Le Jol. Seaweed Extract: Microarray Analysis and Physiological Characterization of N, C, and S Metabolisms. J Plant Growth Regul. 2013; 32: 3152.
Khan W, Rayirath UP, Sowmyalakshmi S, Jithesh MN, Prasanth R, Mark Hodges D, et al. Seaweed Extracts as Biostimulants of Plant Growth and Development. J Plant Growth Regul. 2009; 28: 386399.

Luo HY, Wang B, Yu CG, Qu YL, Su CL. Evaluation of antioxidant activities of five selected brown seaweeds from China. J Med Plants Res. 2010; 4: 2557-2565

Mooney PA, Van SJ. Algae and cytokinins. J Plant Physiol. 1986; 123: 1- 21.

Mohan VR, Venkataraman KV, Murugeswari R, Muthuswami S. Effect of crude and commercial seaweed extracts on seed germination and seedling growth in Cajanuscajan L. Phykos. 1994; 33: 47-51.

Namjooyan F, Azemi M, Rahmanian V. Investigation of antioxidant activity and total phenolic content of various fractions of aerial parts of Pimpinella barbata (dc.) Boiss Jundishapur. J Nat Pharm Prod. 2007; 2: $1-5$.

Pise NM, Sabale AB. Effect of seaweed concentration on the growth. J Phytol. 2010; 2: 50-56.

Rayorath P, Khan W, Palanisamy R, MacKinnon SL, Stefanova R, Simon DH, et al. Extracts of the Brown Seaweed Ascophyllum nodosum Induce Gibberellic Acid $\left(\mathrm{GA}_{3}\right)$-independent Amylase Activity in Barley. J Plant Growth Regul. 2008; 27: 370-379.

Shukla OP, Omkar, Kulshretha AK. Pesticides, Man and Biosphere. APH Publishing Corporation, 1998.

Shozeb J, Aruna P. Effect of biofertilizer, vermicompost and chemical fertilizer on different biochemical parameters of Glycine max and Vigna mungo. Recent Res Sci Technol. 2013; 5: 40-44

Tamilselvan C, Kannan L. Studies on the utilization of seaweeds as fertilizer for black gram. Indian. J Agri Res. 1994; 28: 121-126.

Tay AAB, Mac Leod JK, Palni LMS, Letham DS. Detection of cytokinins in a seaweed extract. Phytochem. 1985; 24: 2611-2614.

Thirumaran G, Kumar P, Anantharaman P. Effect of seaweed extract used as a fertilizer for Abelmoschus esculentus. J Ecobiol. 2006; 19: 373-376.

Thirumal TR, Maria VRS, Peter MM. Effect of seaweed liquid fertilizer on the growth and biochemical constituents of Cyamopsis tetragonoloba (L.) Taub. Seaweed Res Utalin. 2003; 25: 99-103.

Venkatraman K, Mohan VR, Murugeswari R, Muthusamy M. Effect of crude and commercial seaweed extracts on seed germination and seedling growth in green gram and black gram. Seaweed Res Utalin. 1993; 16: 23-27.

Wally O, Alan TC, David H, James SC, Xiumeian, Zaharia LI, et al. Regulation of Phytohormone Biosynthesis and Accumulation in Arabidopsis Following Treatment with Commercial Extract from the Marine Macroalga Ascophyllum nodosum. J Plant Growth Regul. 2013, 32: 324-339. 
Whapham CA, Blunder G, Jenkins T, Wankins SD. Significance of betaines in the increased chlorophyll content of plants treated with seaweed extract. $J$ Appl Phycol. 1993; 5: 231-234.

Williams N, Scott TA, Pratt RM. Forage selection by introduced reindeer on South Georgia, and its consequences for the flora. J Appl Ecol. 1981, 18: 83106.

Received: June 02, 2015; Accepted: August 27, 2015 